\title{
サンプル・ホールド手法を応用した 生糸繊度信号の波形整形“
}

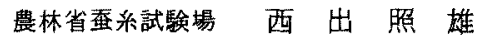 \\ WAVEFORM ARRANGEMENT OF SIZE SIGNAL \\ BY APPLYING SAMPLE AND HOLD TECHNIQUE
}

By Teruo Nishide

(Sericultural Experiment Station, Wada, Suginami-ku, Tokyo, Japan)

\begin{abstract}
An equipment for waveform arrangement was devised to arrange the size signal waveform of raw silk during reeling by applying the sample and hold technique. Furthermore the fundamental characteristics of the equipment were researched, the following results were obtained.

The method of waveform arrangement is to integrate the applied analogue size signal for a set time and hold its value by means of integrator.

In the low frequency range, the frequency of the input has an effects on the output waveform of the proposed device and the waveform is characteristic. On the other hand, the frequency of size signal ( 80 to $95 \mathrm{HZ})$ in the practical reeling speed range (180 to $210 \mathrm{~m} / \mathrm{min}$ ) has no effect upon the output waveform of the device.

The device is a kind of low pass filter because it restrains the high frequency range.

It can be concluded that the optimum range of integration time (=hold time) is from 0.7 to $1.0 \mathrm{sec}$ for practical size control.
\end{abstract}

(Received September 20, 1976)

\section{1. 緒言}

繰采工程に颃いて実時間的に生系紻度情報を収集して 織度制御を実行させるため，実用化には至ってはいない が従来各種の手法を用いた織度検出器の開発が試みられ ている

これらの桙出器によって得られる緎度情報の信号波形 は䧓期・振幅ともに不規則であって，さらに雑至が重畳 している。このため，険出信号のままで政小な㵶度差を 精度よく効果的に検出して, 蚐一な瀻度を有する生系を 繰製することは困難である。従って㛟出信号にもとづい て瀻度を計数化あるいは䋐度制御を実行させるためには、 それらの目的に合致した信号波形に検出信号波形を波形

*この報交を「繰糸工程に括ける生系絨度の計測制御に 関する研究 (第3 報)，Studies on the size measure ment and control of raw silk during the reeling process (Part 3)」とする。
整形する必要がある。

繰系中に括いて落緒，接緒など蔽米の增减によって急

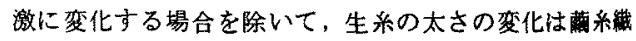
度曲線 ${ }^{9\rangle}$ に従う改小なものであるが，䋐度信号波形の振 幅は微小な織度変化よりも激しく変化する。そのため， サンプル・ホールドだけで瀻度制御を実行した場合、こ のホールダーからの出力は振幅の影響を受けることが予 想され，制御判断と制御動作を安定した状態で実行する ことは困難と考える。従って区間積分とサンプル・ホー ルダとの構成にすれば前述した振幅の影響の問題点は解 決し，さらにこの構成による出力信号はステップ状とな るので区間積分時間ごとの出力差が明確になるとともに， 出力の数値化への処理が比較的簡単になると考える。

本報はサンブル・ホールダーと区間皘分との構成によ る生系紻度信号の波形整形について報告する。 


\section{2. 装置と方法}

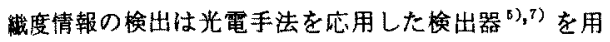
Wた。

㬰験装置と方法は図1のブロック図に示す。すなわち， 綝系中の生糸瀻度情報は娭出器によって電王信号として 倹出される。その信号は利得調整されて，任意に設定さ れた時間だけ積分器によって積分されつつサンブル・ホ ールダーによって保持される。積分された情報は次にス テップ状の波形として時間 $t$ だけ出力される。この時間 ただけステップ状の波形として，今出力されている情報 は，今から時間 $t た ゙ け$ 前に積分された情報である。

一次遅れ要素を持つ低域洰波器を併設した目的は，こ の洰波器の出力波形と前述した波形整形器の出力波形と を比較検討するためである。

な㧍，本報において報告する波形整形器（主として皘 分器，サンブル・ホールダーから成る)をここで区間 潄分器と定義して执く。

波形整形のために試作した区間積分器および一次遅れ の呧域汇波器の概略回路図を図 2 の，Bにそれぞれ示 す。

区開磧分器 (図 $20 \mathrm{~A}$ ) は利得調整 $\left(R_{g}\right),>_{\uparrow}-\vdash$ $\therefore$ $\left(R_{f}\right)$ ，時間設定 $\left(R_{t}\right)$ のための各抵抗，積分器, 零次のサンブル・ホールダー，発信器，時間設定用 LED ランブ等から構成されている。

積分時閒，すなわちホールド時間は，LEDランプのフ ラッシェが設定する時間間隔になるように、 $R_{t}$ を調整す ることによって任意に設定することができる。

䞍分器への入力信号 $f_{i}(t)$ を正弦波と寸れば，その出 力信昭 $f_{0}(t)$ は (2) 式として示すことができる。従って 輤分器の伝達関数 $G_{1}$ は (1)，(2) 式加ら（3）式となる。

$$
\begin{aligned}
& f_{i}(t)=a \sin \omega t \\
& f_{0}(t)=\int_{0}^{t} a \sin \omega t d t \\
& G_{1}=\frac{L\left\{f_{0}(t)\right\}}{L\left\{f_{i}(t)\right\}}=\frac{1}{S}
\end{aligned}
$$

零次ホールドの伝達算数 $G_{2}$ は $(4)$ 式で示されている

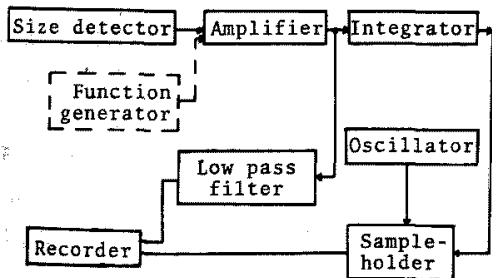

Fig. 1 Block diagram of experimental equipment.

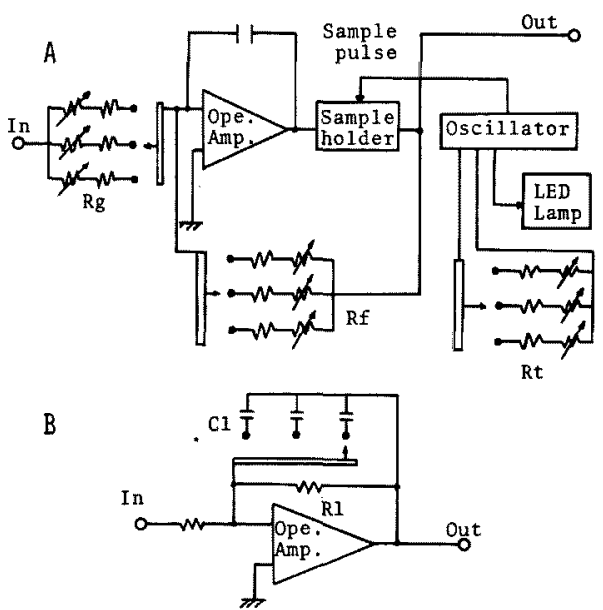

Fig. 2 Circuits for waveform arrangement.

A : Apparatus for waveform arrangement with integrator and sample holder.

B : Low pass filter with first-order lag.

$R_{g}$ : Gain adjustment resistance.

$R_{f}:$ Feed back resistance.

$R_{t}$ : Resistance for integrating time set.

$G_{2}=\frac{1-e^{-s t}}{S}$

図 2のBは一次遅れの低域洰波器の回路を示したもの で，図中の $C_{1}$ と $R_{1}$ との組み合せによって時定数を設定 できる。の沪波器の层達関数 $G_{3}$ は(5)式として示され ているき。

$$
G_{8}=\frac{1}{1+T S}
$$

\section{3. 結果と考察}

\section{1 基本的特性について}

繰系中に得られる䋐度情報の信号波形は不規則てはあ るが，基本的な各種の信号波形，たとえば正弦波，三角 波，矩形波，のこぎり歯波等の波形がいろいると複雑に 組み合わさっているものと考える。

入力信号が基本的には区間㮖分器によってどのような 波形に変換されて出力されるのかを，まづ知っておく必 要があるので，前述した基本波形を入力信号として，本 器の出力波形について娭討した結果を図 3 に示す。

図3の結果から判断できるように，本器の波形整形の 特改はアナロダ量による入力を一定時閶積分してホール ドし，その結果をステップ状の波形に変換することであ るが，その出力は皘分時間，すなわちホールド時間だけ 遅れる。

樍分時間が一定であれば，入力周波数によって出力さ 
れる出力波形が異なることは容易に想像できる。そこで 入力周波数と出力波形との関係について検討する。

図 4，5は正弦波抬よび矩形波を入力信号として，積 分時間を 0.25 秒とした場合の周波数と出力波形との関 係の1 部を例示したものである。

この結果，入力周波数の增大とともに入力波形とは異 なる出力波形が出力され，入力䧓波数が $50 \mathrm{~Hz}$ を越える と出力波形はほぼ直線状になる。さらに周波数とともに

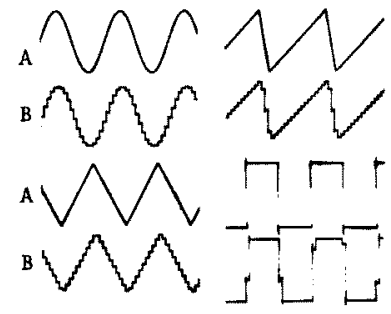

Fig. 3 Fundamental characteristics of arranged waveform.

A: Input waveform. B: Output waveform. Frequency of input is $0.2(\mathrm{HZ})$ and integration time equal to sample-hold time is 0.25 (sec).

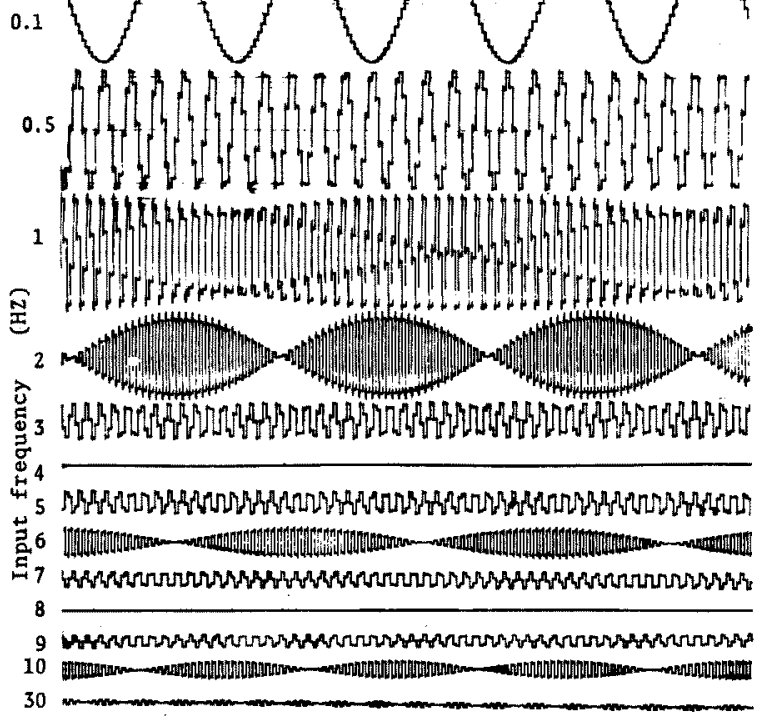

Fig. 4 Effects of input frequency on output waveform. Integration time equal to sample-hold time used is 0.25 (sec) and waveform of input is sine wave.
変化する出力波形には一定の規則性が存在していることが わかる。すなわち, 奉験結果から入力周波数が(6)式て示 される場合の出力波形はほぼ直線であり(たと立ば图4， $5 の 4,8 \mathrm{~Hz}$ )，(7) 式で示される場合の出力波形は特 有な波形（たとえば图 4,5 の $2 ， 6 ， 10 \mathrm{~Hz}$ )を示寸。

$$
\begin{aligned}
& f_{n} \cdot t=n \\
& f_{n} \cdot 2 t=n
\end{aligned}
$$

$f_{n}$ : 入力周波数 $\left(\mathrm{H}_{2}\right)$

\section{$t:$ 棈分時間 $(\mathrm{sec})$}

\section{$n:$ 正の整数}

本㬰験の場合，入力周波数が $50 \mathrm{~Hz}$ 越えると出力波 形はほぼ直線状となることから，(6)，(7)式が前述し た特有な出力波形と対応して成立つためには $n$ の筙冊加 限定される。このnの艘柬を算出すれば， $1 \leqq n \leqq 12$ と なる。このnの籍囲は積分時間が異なる場合の図 6 の結 果と一致している。

入力周波数加（6）式を満足する場合，本器の出力波形 が直線状を示す理由は次のように考える。程分時間が 0.25 秒，すなわち周期に換算すれば $4 \mathrm{~Hz}$ でるから， 周期的にブラス，マイナスをくりかえ寸入力信号の $4 N$ 倍の周波数の信号の積分值は零となるためである。この 事は積分時間を商用のN倍にすることによって， 商用電源からの誘導ノイズを除去することがて きることと同義と考える。

$(6,7)$ 式でnが整数でない場合の出力波形 （たとえば図 4，5の3 Hz）を良く稌討すると， その出力波形の中に(7) 式に対応する波形が包 含されていることが認められる。

なお，三角波，のこぎり電波を入力した場合 の出力波形は正弦波を入力とした場合と同様な 波形を示した。

樻分時間を $1 ， 2.5$ 秒とした場合の入力周波数 (入力波形は正弦波)と出力波形との関俰を园 6 に示寸。

この結果，積分時間が長くなるに従って，図 4 で示した特致的な出力波形が出現する周波数 は低周波数側に規則的にシフトすることが認め られた。すなわち, 皘分時間が $1,2.5$ 秒の時は 0.25 秒の時にくらべて，それぞれ 4, $10 \mathrm{~Hz}$ け低周波数側にシフトして，四 4 と全く同じ出 力波形を示す。

このような実験結果から，同一の出力波形を示 与人力閏波数 $f_{1} ， f_{2}$ と，その時の積分時間 $t_{1}, t_{3}$ との関倸は (8) 式となる。この事は図 4 と图 6 の結果を比較すれば容易に理解できる。

$$
f_{1} t_{1}=f_{2} t_{2}
$$




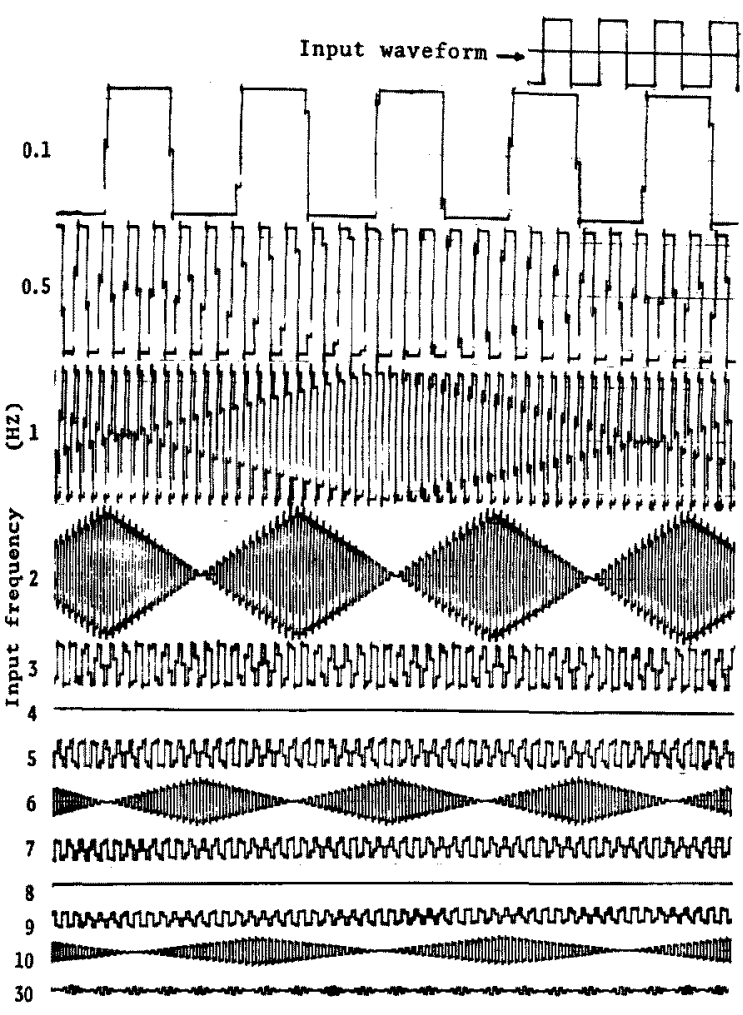

Fig. 5 Effects of input frequency on output waveform. Integration time equal to sample-hold time used is 0.25 $(\mathrm{sec})$ and waveform of input is rectangle wave.

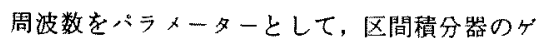
イン特性について検討した結果を図7に示す。 この梌討力法は图 7中に示すよらに，入力扰よ び出力波形のピークからピークまでの距離をそ れぞれ $L$ (一定)，L'として，各周波数における その比 (し'/L)を算出したものである。

この結果から、サンプル値制御系に扔ける周 波数特性と同㥞に ${ }^{10)}$, 本波形整形器は高调波成 分を抑制する一種の低域沪波器と考えることが でき。

併設した洰波器（図 2-B）の周波数特性につ いて，区間積分器のそれ(図7) と比較するた めには同一の時定数を持つことが必要である。 そこで, 図 2-Bの洰波器の時定数は $R_{1}$ と $C_{1}$ と の組み合せ，才なわち $25 \mathrm{~K} \cdot 10 \mu, 21 \mathrm{~K} \cdot 47 \mu$, $25 \mathrm{~K} \cdot 100 \mu$ として区間皘分器の $0.25,1.0,2.5$ 秒と対応させた。夷験方法は图 7 と同様に行な い,その結果を図 8 に示す。

この結果，時定数が大きくなるとともに，出 力波形の振幅虫ささくり，一定の周期を示し ながらゲインが隇少するとともに，高調波成分 を抑制する特性を示した。

\section{2 生糸繊度信号の波形整形}

前報『)で述べたように㵶度情報の倹出方法は， 走行する生系と偏心鼓車との接触によって生系 が測定光束を周期的に遮断して，その陰光量を 䋞度情報として検出するものである。そのため 検出される㵶度信号の周波数は繰禾速度に影響 を受けると考えられる。そこで，前述したよう

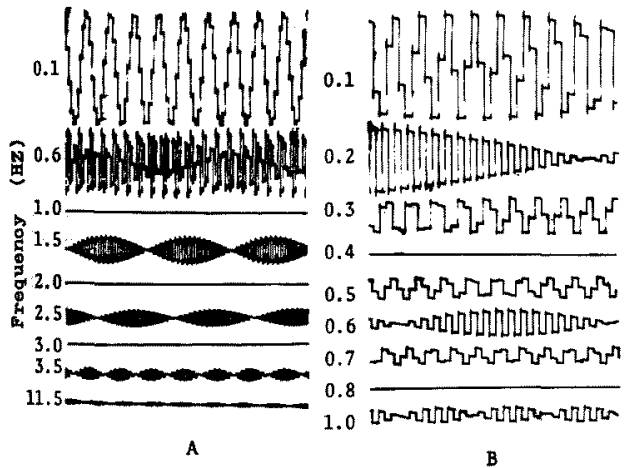

Fig. 6 An example of relation between input frequency, integration time and output waveform.

Integration time of $A$ is $1.0 \mathrm{sec}$ and $B$ is $2.5 \mathrm{sec}$. Waveform of input is sine wave.

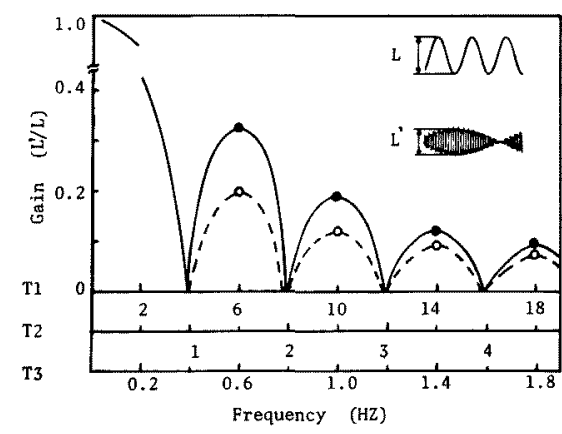

Fig. 7 Relation between gain and frequency. Gain $(L / L)$ is calculated using the experimental results as is shown in figure.

$\rightarrow$ : In case of rectangle wave.

$i_{1}$ : In case of sine wave.

$T$ is integrated time; $T_{1}=0.25 \mathrm{sec}$.

$T_{2}=1.0 \mathrm{sec} . T_{3}=2.5 \mathrm{sec}$. 


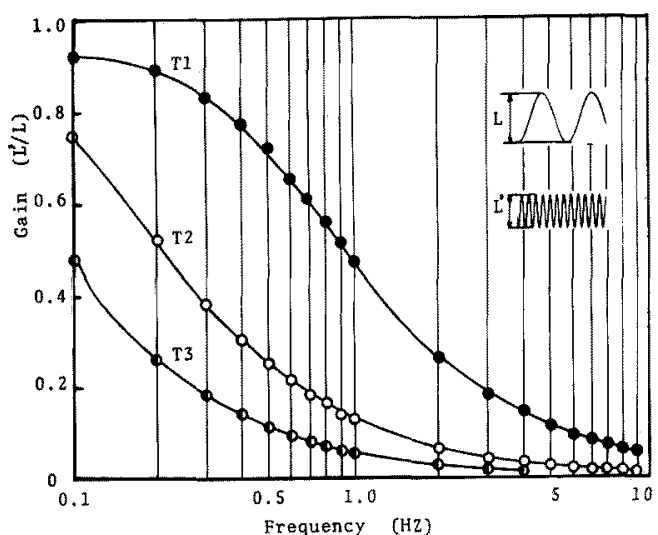

Fig. 8 Relation between gain $\left(L^{\prime} / L\right)$ and frequency by low pass filter with first-order lag.

Time constants of $T_{1}, T_{2}$ and $T_{3}$ are $0.25,1.0$ and $2.5 \mathrm{sec}$.

に本整形器は入力周波数に影響を受けるので，紻度信号 の周波数を知って抢く必要がある。この目的から，繰系 速度と緎度信号の周波数との成係について検討した結果 を図 9 に示才。

この測定方法はストロポスコープを用いて，各繰系速 度ごとの扁心敨車の1秒当りの回転数から緎度信号の周 波数を算出した。すなわち，偏心鼓車 1 回転につき系条 は測定光束を 2 回遮断するから，凬波数は1秒当りの偏 心鼓車の回転数を 2 倍した値となる。

この結果，繰糸速度の上昇とともに信号の周波数は增 大することが認められた。一方，現在の奏用的な絽系速 度は180 210 $\mathrm{m} / \mathrm{min}$ であり，その速度域に扔ける周 波数は約 80〜 95 Hz であることが図 9 からわかる。基

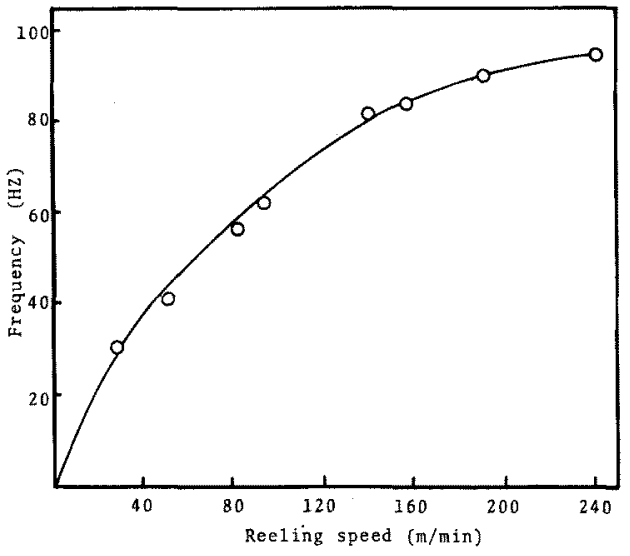

Fig. 9 Plots frequency of size signal vs reeling speed.
本波形を入力した場合ではあるが図 4，5に示したように， この周波数带において，本整形器の出力波形怙值線状と なる。

このことから，実用上の繰系速度から得られる瀻度信 号の周波数が，本整形器の出力波形におよ活す影䅛住な いと考える。

繰系中の㵶度情報を収集して，その信号を本整形器と 一次遅れの低域洰波器(図2のA，B）とを用いて，波形 整形した結果を図 10 に示す。低域泎波器に使用した各 定数は図 9 と同じである。

この結果から、皘分時間が長くなるに従って区間糟分 器，低域沪波器ともに波形整形された信号波形は，平均 化が進んでなめらかな波形になり，微少な瀻度変化を能 出しにくくなると同時に，信号の変化に対する応答速度 も遅れる。一力，積分時間が短いと整形された信号波形 は凹凸が激しく，瀻度制御判断括よび事行を電気的，機 械的に安定した状態で行なうには不適であり，さらには 織度制御系をみだすことも考えられる。

現行の自動繰系機の接緒器が接䋨指示を受けてから1 接緒動作を完了するために必要な時間は 0.7 秒である。

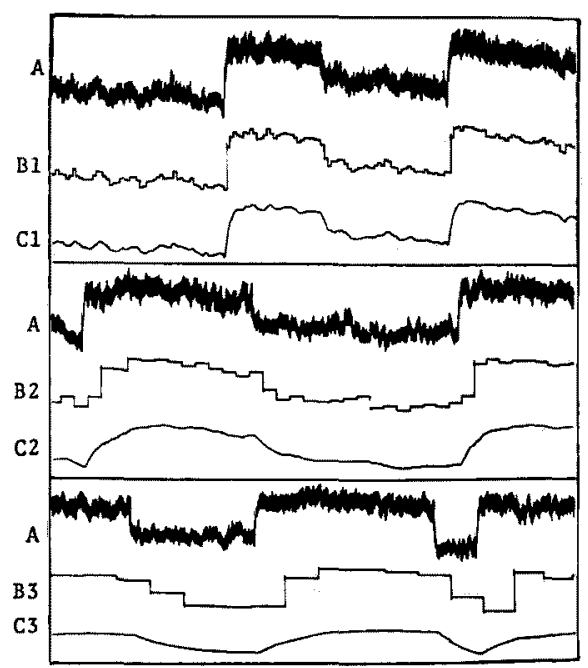

Fig. 10 Relation between original waveform and arranged waveforms of size signal.

A: Original waveform of size signal.

B : Arranged waveform by means of wave arrangement device as is shown in Fig. 2-A and integrated times of $\mathrm{B} 1, \mathrm{~B} 2$ and $\mathrm{B} 3$ are $0.25,1.0$ and $2.5 \mathrm{sec}$.

$C$ : Arranged waveform by means of low pass filter with first-order lag and time constants of $\mathrm{C} 1, \mathrm{C} 2$ and $\mathrm{C} 3$ are $0.25,1.0$ and $2.5 \mathrm{sec}$. 
落緒の時間的出現はランダムではなく，䍘系長を周期 とする弱い周期性があることが認められているが泫，実 用面に招いて綝系中にいつ落緒が発生して急激に生系の 太さが紐くなるかかからない。従って織度制御判断を行 なうためのサンブリング時間は短い方が禾むらの面から 好ましい。さらに移動平均演算による周波数沁答特性 ${ }^{12)}$ によれば，同一周波数の場合，移動平均時間が長くなる に従ってゲインは减少し，位相角もてれに従ってずれ が大きくなることが理論的に示されており，本報の実験 結果 (図7)とも一致している。

以上のことから積分時間は短い方が望ましいが、前述 した接緒機構の制䄪から 0.7 秒より短くすることは好ま しくないここことは 1 接䋨動作が完了しないらちに， さらに次の接緒指示が出力された場合、機柀的に安定し た状態で接緒動作を行なうことが困難となるためである。 图10における積分時間が 1 秒の場合の整形信号波形は 原俄度信号の変化に対応していることと, 前述した諸理 由から適当と思われる積分時間(ホールド時間)の範間 は0.7一1秒と考える。

\section{4. 結語}

綝系中の生糸瀻度情報の信号波形を波形整形与る目的 から、サンプル・ホールト手法を応用した波形整形器を 試作して，一次荤れ要素を持つ低域洰波器とともにその 基本的な特性について検討を行ない，次の結果を得た。

1）区間積分器の波形の整形方法は，アナロダ量て入 力される䄉度信号を設定時間だけ積分しながらホールド するものである。そのため坎答には迤れがともなう。本
器の出力波形はステップ状である。

2) 区間積分器の出力波形は入力周波数の低周波数域 において影響を受け，特有な波形を示す。また，謮分時 間(ホールド時間)が長くなると, 特有な波形は低周波 数側にシフトする。一方，実用的な線糸速度域に招ける 驖度信号の周波数は，出力波形に影響を与えない。

3）区間積分器は高調波成分を抑制する特性を持って いて，低域洰波器の範ちゅらに属する。

4）実用的に適当上思われる区間皘分器の軉分時間 (ホールド時間) と一次荤九の低域洰波器の時定数の範 用は 0.7〜1秒と推察する。

\section{文献}

1）河田末吉, 瀬川 繁；緎機誌，4，500(1952)

2）㷁口健治，大野克躬，関根俊、士橋俊人；製系 絧研究発表抄録，3，153(1953)

3）柳原茂；者系試験場報告，16，113(1960)

4) 西出照雄; 日垔雑，45，46(1976)

5) 西出照雄; 瀻学誌, 32,T 440 (1976)

6）小野四郎；生糸の品質向上に関する繰系の基礎的 研究 (学位論文), p. 10-14(1966)

7) 西出照雄；絨学誌, 32, T 445 (1976)

8）例えば，上滝致孝；「自動制御理諭」（礎部ほか 編), p. $171 \sim 172$ ，共立出版（1962）

9）例えば宮崎孔友；「計測工学」，p.5，朝倉書店 (1972)

10）例えば，藤井澄二編；「岩波基礎工学・制御工学 III」,p.112，岩波書店（1973）

11）鴆崎昭典；日㔻雑， 26，T 182 (1957)

12) 青木 朗; 絨学誌, 15, 466 (1959) 